INTERNATIONAL JOURNAL OF RESEARCHES IN BIOSCIENCES, AGRICULTURE AND TECHNOLOGY (C) VISHWASHANTI MULTIPURPOSE SOCIETY (Global Peace Multipurpose Society) R. No. MH-659/13(N) www.ijrbat.in

\title{
SCOPARIA DULCIS VAR ABRAHAMII PARDESHI \& SRINIVASU (PLANTAGINACEAE): AN EXTENDED DISTRIBUTIONAL PLANT RECORD TO VIDHARBHA REGION OF MAHARSHTRA STATE, INDIA
}

\author{
Mukund B. Shende and Umakant B. Deshmukh \\ Higher Learning and Research Centre and P.G. Department of Botany, \\ Janata Mahavidyalaya, Chandrapur . 442401 (Maharashtra),India. \\ deshmukhumakant979@gmail.com
}

\begin{abstract}
:
During the field exploration from Chandrapur district an interesting plant of family Plantaginaceae collected from Vidharbha region of Maharashtra state. After critical observations of specimen and review of relevant literature it was identified as Scoparia dulcis var. abrahamii Pardeshi \& Srinivasu. It is reported as an extended distributional record to the Vidharbha region. A detailed taxonomic description, distribution and images of the species are provided along with a taxonomic key for easy identification.
\end{abstract}

Keywords: Scoparia dulcis var. abrahamii , Plantaginaceae, Vidharbha,, Maharashtra

\section{INTRODUCTION:}

Scoparia L. genus is representatives of the Gratioleae, a mainly Neotropical tribe of Plantaginaceae family (Estes \& Small, 2008). Recent molecular phylogenetic studies have shown that Amphianthus, Bacopa, Gratiola, Mecardonia, Otacanthus, Scoparia, and Stemodia belong to a strongly supported tribe Gratioleae (Olmstead et al. 2001; Albach et al. 2005; Oxelman et al. 2005; Rahmanzadeh et al. 2005). According to Fay et al. (2010) many non-parasitic members of Scrophulariaceaesensulato.included in the family Plantaginaceaesensu APG III (2009).

Scoparia L.genus comprises from 10 to 20 species, depending on circumscriptions (Fries 1906; Barroso 1952; Souza \& Giulietti 2009). In Maharashtra only one species reported Scopariadulcis L. (Singh \& Kartikeyan, 2001; Almeida,2001). Recently Pardeshi \& Srinivasu (2009) reported new variety Scoparia dulcis var. abrahamii Pardeshi \& Srinivasu from Mumbai, Maharashtra state.

\section{METHOD AND MATERIAL:}

The taxonomic survey was done to identify the distribution of the plant under study. It was followed by a detailed taxonomic investigation.

\section{RESULT AND DISCUSSION:}

An occurrence of Scoparia dulcis var abrahamii Pardeshi \& Srinivasu (Plantaginaceae) from Chandrapur district shows an extended distributional record to Vidharbha region of Maharashtra state.

\section{Key to the variety of Scopariadulcis}

1. Corola lobes 4-5, oblong sub-acute, falcate, white with pinkish ting to entire lobes

\section{...var. abrahamii}

2. Corola lobes 4 , oblong round, not falcate, white with purplish ring at the base of lobes ...... var. dulcis

Characteristics that separate Scoparia dulcis var. abrahamii from Scoparia dulcis listed as follows in Table no. 1 .

Taxonomic Treatment :

Scoparia dulcis var. Abrahamii Pardeshi \& Srinivasu. NELUMBO, 51; 231-232, 2009 (Plate, No.01).

Description: Under shrub , 50-100 cm height, perennial, bushy, erect, densely branched and usually three braches at each node; Stem glabrous, farinose with fine white dots, dull green, ridged, 4-5 angled at base, young branches 4-8 angled, pale 
green; Internodes up to $6.5 \mathrm{~cm}$ on main stem and $0.6 \mathrm{~cm}$ on branches; Leaves foetid, simple, glabrous, exstipulate; Petiole slender, glabrous, 1-0.4 cm long; Lamina $0.5-2.3 \mathrm{~cm}$ long and 0.3-1 cm broad, deep green above and pale beneath, rhomboid-obovate larger leaves, and 3-nately whorled on main stem and smaller linear-spathulate leaves on branches with both opposite and 3-nately whorled; Margin entire up to the middle of lamina and slightly serrated from the middle of the lamina or slightly towards the apex, lamina glabrous on both surface ,broader in the middle and tapering towards both ends, acute apex, base tapering ,punctuate beneath; Venation reticulate, 3 main nerves, alternate poorly prominent; Flowers pedicilate, bisexual, complete, solitary or 2, axillary, tetramerous, hypogynous, actinomophic, white with pinkish tinge ,0.4-0.5×0.6$0.9 \mathrm{~cm}$ across; Pedicel $0.4-0.5 \mathrm{~cm}$ long; Calyx valvate, persistant, companulate divided up to the base, 4 sepals, ovate, $0.2 \mathrm{~cm}$ long with 3 parallel nerves, ciliolate and puberluent; Corolla rotate, fugacious, valvate, tube less than $0.1 \mathrm{~cm}$, pilose with many $0.2 \mathrm{~cm}$ long hairs ;Petals usually 4 ,frequently fifth petal also present, petals 0.3$0.4 \times 0.15 \mathrm{~cm}$ long white with pinkish ting, oblongsub-acute somewhat falcate, equal; Stamens 4-5, epipetalous, equal, inserted at the base of corolla tube; Filaments glabrous, equal, 0.2-0.25 cm long, white at the base and pinkish at apex, Anther dithecous, pale yellow, $1.5 \mathrm{~mm}$ long, oblong-subsaggitate, extrose, dehiscence longitudinal; Style 0.2 $\mathrm{cm}$ long, terminal, white at the base and pinkish from middle to the apex; Stigma capitates; Carpels 2, syncarpous; Ovary superior, bilocular, many ovules in each locule, axile placentation; Fruit loculicidal capsule, pale brown, glabrous, ultimately bifid, sub - globose or sub-ovoid, $0.2-0.3 \mathrm{~cm}$ long $\times$ $0.3 \mathrm{~cm}$ across, persistent style base at the apex and persistent calyx surrounding more than half wavy ,membranous valves; Seeds many, oblong, dark brown, shortly apiculate at one end with small pitting.
Habitat: Weed along the Roadside.

Flowers and Fruiting- Whole year in favourable condition.

Dstribution In Maharashtra- Mumbai, Chandrapur (Now it is collected by Umakant Deshmukh on dated 15 April, 2018, from Ramnagar area of Chandrapur city, GPS location N 1957'.44.1",E 79¹7'.13". Herbarium specimen deposited at P.G.Department of of Botany Janata Mahavidyalay, Chandrapur (Voucher No.612).

\section{CONCLUSION:}

The extended distributional record of Scoparia dulcis var. abrahamii Pardeshi \& Srinivasu from the Vidharbha region of Maharashtra, India was reported. A detailed taxonomic description, distribution and images of the species are provided along with a taxonomic key for easy identification of the plant variety under study.

\section{ACKNOWLEDGEMENT}

The authors are thankful to Dr. T Srinivasu, Head Department of Botany,RTM Nagpur University for the identity of variety. And Dr. M. Subhash, Principal and Dr. Y. B Gedam Head, Department of Botany, Janata Mahavidyalay, Chandrapur for providing laboratory facilities.

\section{REFERANCE :}

Albach, D.C.,H.M.Meudt and B.Oxelman (2005) Piecing together the "new" Plantaginaceae. American Journal of Botany 92: 297-315.

Almeida, M.R. (2001) Flora of Maharashtra-Vol. 3 a \& b. Blatter Herbarium, St. Xavier's College, Mumbai, pp. 414.

APG III (2009) An update of the Angiosperm Phylogeny Group classification for the orders and families of flowering plants: APG III. Botanical Journal of the Linnean Society 161: 105-121.

Barroso, G.M. (1952) Scrophulariaceae indigenase exóticas do Brasil. Rodriguésia27: 9-64.

Estes, D.\&R.L.Small (2008) Phylogenetic relationships of the monotypic genus 
Amphianthus(Plantaginaceae tribe Gratioleae) inferred from chloroplast DNA sequences. Systematic Botany 33: 176-182.

Fay, M.F., J.R. Bennett, K.W. Dixon, and M.J.M.Christenhusz, (2010) Parasites, their relationships and the disintegration of Scrophulariaceaesensulato.Curtis's Botanical Magazine 26: 286-313.

Fries, R.E. (1906) SystematischeÜbersicht der GattungScoparia.ArkivförBotanik 6: 1-31.

Olmstead, R.G.,C.W.Depamphilis, A.D. Wolfe, N.D.Young,W.J.Elisons and P.A.Reeves (2001) Disintegration of the Scrophulariaceae. American Journal of Botany 88: 348-361.

Oxelman, B.,P.Kornhall,R.G.Olmstead and B.Bremer (2005) Further disintegration of Scrophulariaceae. Taxon 54: 411-425.

Pardeshi,S.N. and T.Srinivasu (2009) A new variety of Scopariadulcis L.(Scrophulariaceae ) from Mumbai (Maharshtra ),India.Nelumbo,51;231232

Rahmanzadeh, R.K.,MullerE.Fischer,D.Bartels and T.Borsch (2005) The Linderniaceae and Gratiolaceae are further lineages distinct from the Scrophulariaceae (Lamiales). Plant Biology 7: 67-78.

Singh N. P and S. Karthikeyan (eds.) (2001) Flora of Maharashtra-Vol. II. Series 2. Botanical Survey of India, Kolkata, pp. 546.

Souza, V.C.and A.M. Giulietti (2009) Levantamento das espécies de Scrophulariaceaesensulatonativas do Brasil. Pesquisas, Botânica 60: 7-288. 
Table no.1.Comparison of varieties of Scopariadulcis .

\begin{tabular}{|c|c|c|}
\hline Character & Scopariadulcisvarabrahamii & Scopariadulcis \\
\hline $\begin{array}{l}\text { Leaf } \\
\text { Colour } \\
\text { Margin }\end{array}$ & $\begin{array}{c}\text { Dark green } \\
\text { Slightly serrated ,Starts from the middle of } \\
\text { the leaf or towards the apex }\end{array}$ & $\begin{array}{c}\text { Pale green } \\
\text { Deeply serrated ,Starts from before the } \\
\text { middle of the leaf }\end{array}$ \\
\hline $\begin{array}{l}\text { Corola Lobe } \\
\text { Number } \\
\text { Size } \\
\text { Shape } \\
\text { Colour }\end{array}$ & $\begin{array}{c}\text { 4-5 lobes } \\
\begin{array}{c}3.5-4 \times 1.5-2 \mathrm{~mm} \\
\text { Oblong , sub-acute and falcate }\end{array} \\
\text { White with pinkish ting to entire lobes }\end{array}$ & $\begin{array}{c}\text { 4 lobes } \\
2.8-3 \times 1.5-2 \mathrm{~mm} \\
\text { Oblong round and not falcate } \\
\text { White with purplish ring at the base } \\
\text { of lobes }\end{array}$ \\
\hline
\end{tabular}
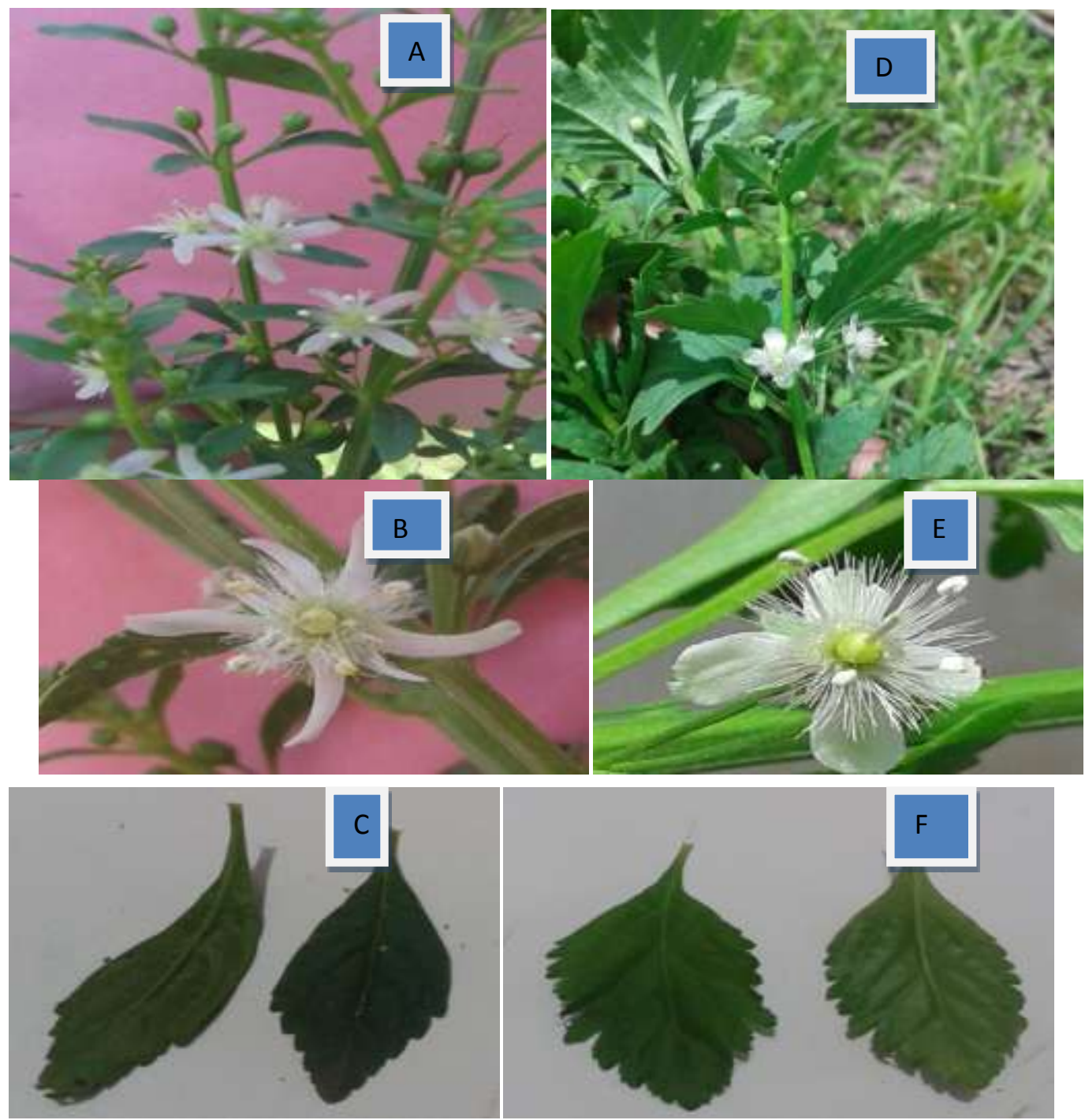

Plate.No. 01.Fig.A-C.Scopariadulcisvarabrahamii. A-Flowering branch;B-Single flower ;C- Leaf showing dorsal and ventral side. Fig-D-F.Scopariadulcisvar.dulcis D-Flowering branch ;F-Single flower ;F- Leaf showing dorsal and ventral side. 